\title{
ANALISIS EFEKTIFITAS PROGRAM PINJAMAN DANA BERGULIR PADA UNIT PENGELOLA KEGIATAN (UPK) PNPM MANDIRI DI KECAMATAN MOJOWARNO KABUPATEN JOMBANG TAHUN 2014
}

\author{
Agus Taufik H. \\ Dosen STIE PGRI Dewantara Jombang
}

\begin{abstract}
This study aims to analyze the effectiveness of activities revolving Unit Pengelola Kegiatan (UPK) Mojowarno subdistrict PNPM Mandiri in 2014. Indicators used to measure effectiveness is in the form of performance instrument measuring the ratio CCR, ROI, PAR, LAR.This type of research is qualitative descriptive. This study uses secondary data derived from the financial statements in the form of funds flow statement, balance sheet and income statement in 2014. The data was analyzed using a model of Miles and Huberman. Results of analysis of the effectiveness of the CGU districts Mojowarno 2014 indicate that the value CCR> $125 \%$ is equal to $219 \%$, which means an effective, ROI figures show $26 \%$ are categorized as effective as $>10 \%$, PAR is considered effective because the value obtained $<10 \%$ is equal to $6 \%$, and LAR in the category are not effective because of $\geq 20 \%$, ie by $21 \%$.
\end{abstract}

Key words: effectiveness, program revolving fund, Activity Management Unit

\section{A. Pendahuluan}

Beberapa konsep pembangunan di negara berkembang gagal dalam mengentaskan kemiskinan dikarenakan memisahkan pembangunan sosial dan pembangunan ekonomi. Padahal keberhasilan di negara-negara industri maju karena penekanan yang diberikan pada bidang pendidikan dan kualitas sumber daya manusia. Oleh karena itu perlu menilai kembali upaya mengatasi kesenjangan yang terjadi khususnya bagi masyarakat miskin yang semakin jauh dari kesejahteraan. Salah satu upaya mengatasi hal tersebut adalah meletakkan strategi pemberdayaan masyarakat sebagai strategi pengentasan kemiskinan. Masalah kemiskinan menyangkut hak-hak dasar 
masyarakat untuk mempertahankan dan mengembangkan kehidupan yang bermartabat.

Sebagai upaya serius dalam meningkatkan efektifitas penekanan angka kemiskinan, pemerintah telah memiliki konsep penanggulangan kemiskinan secara terpadu dengan basis pemberdayaan masyarakat dimana masyarakat sebagai subjek penanggulangan kemiskinan bukan objek dengan kata lain pemerintah telah meperhatikan faktor partisipasi sebagai salah satu faktor penentu keberhasilan dalam program pengentasan kemiskinan. Program yang diresmikan oleh Presiden Susilo Bambang Yudhoyono di Palu pada tanggal 1 Mei 2007 bernama program Nasional Pemberdayaan Masyarakat (PNPM) Mandiri. Program Ini terdiri dari beberapa program penanggulangan kemiskinan salah satunya Program Nasional Pemberdayaan Mandiri Perdesaan atau disingkat menjadi PNPM Mandiri perdesaan yang sebelumnya bernama PPK (Program Pengembangan Kecamatan).

Program Nasional Pemberdayaan Mandiri Perdesaan (PNPM Mandiri perdesaan) merupakan salah satu mekanisme program pemberdayaan masyarakat yang digunakan PNPM Mandiri dalam Upaya mempercepat penanggulangan kemiskinan dan perluasan kesempatan kerja di perdesaan. Program ini dilakukan untuk lebih mendorong upaya peningkatan kualitas hidup, kesejahteraan dan kemandirian masyarakat di perdesaan.

PNPM Mandiri Perdesaan terbagi dalam tiga kegiatan utama yaitu 1) Penyediaan prasarana sosial ekonomi bagi peningkatan kesejahteraan masyarakat, dengan penekanan bahwa prasarana yang dibangun, 2) Peningkatan kualitas hidup masyarakat miskin melalui bidang pendidikan dan kesehatan, termasuk kegiatan pelatihan pengembangan kemampuan masyarakat dan bantuan manajemen usaha, dan 3) Perluasan kesempatan berusaha dan peluang pengembangan usaha bagi masyarakat miskin yang meliputi kegiatan Usaha Ekonomi Produktif (UEP) dan Simpan Pinjam Khusus Perempuan (SPP).

Kegiatan Usaha Ekonomi Produktif (UEP) dan Simpan Pinjam Khusus Perempuan (SPP) dikelola oleh suatu lembaga bernama Unit Pengelola Kegiatan (UPK). Unit Pengelola Kegiatan (UPK) sebagai lembaga pengelola kredit mikro di tingkat kecamatan mempunyai potensi yang besar untuk dapat 
berperan dalam mengurangi kemiskinan dengan memberikan akses kredit kepada masyarakat miskin. Salah satu unsur yang sangat diperhatikan oleh UPK adalah kinerja UPK tersebut. Untuk melihat pencapaian pelaksanaan kegiatan UPK diperlukan kajian-kajian sehingga dapat memberi gambaran mengenai penilaian efektifitas suatu kelompok dalam mengelola sesuatu yang telah berhasil dicapai. Efektifitas merupakan pengukuran yang memberikan gambaran seberapa jauh target dapat dicapai (Husein, 2005).

Indikator dalam mengukur efektifitas yang digunakan adalah instrumen pengukur kinerja tahun 2014 yaitu berupa rasio keuangan CCr, ROI, LAR, PAR yang ditujukan untuk mengukur kesehatan UPK dan kaitannya dengan kesiapan warga dalam menerima intervensi lanjutan dari pemerintah untuk tahun berikutnya (Kementrian Koordinator Bidang Kesejahteraan Sosial, 2014).

CCr atau Cost Coverage Ratio, mengukur berapa besar rasio pendapatan dibandingkan biaya. Berapa pendapatan yang meng-cover biaya. Dikatakan berkinerja baik apabila lebih besar dari $125 \%$, artinya bila UPK berani untuk mengeluarkan biaya Rp 100, maka UPK harus dapat memperoleh pendapatan minimal Rp 125.

Berikutnya ROI atau Return on Investment, menunjukkan kemampuan UPK dalam menghasilkan laba. Dikatakan sehat apabila UPK PNPM dapat memperoleh laba minimal 10\% pertahun, ini berarti jika UPK PNPM mengelola dana bergulir Rp 60.000.000, maka minimal laba pertahun adalah Rp 6.000.000.

Selanjutnya Portofolio At Risk atau disingkat dengan PAR, menunjukan jumlah KSM yang beresiko hilang atau menunggak lebih dari tiga bulan. Dikatakan PNPM dalam kondisi sehat apabila LAR kurang dari 10\%, ini berarti bila dana bergulir dikucurkan kepada 24 KSM maka KSM yang bermasalah harus kurang dari 2 KSM.

Yang terakhir adalah LAR atau Loan At Risk, yang menunjukkan sejumlah nilai dana bergulir dalam beresiko hilang atau menunggak lebih dari tiga bulan. Dikatakan sehat apabila PAR kurang dari 10\%, yang berarti dari Rp60.000.000, dana yang ditolelir dalam keadaan menunggak lebih dari 3 bulan maksimal Rp6.000.000. 
Analisis Efektifitas Program Pinjaman Dana Bergulir pada ...

Karena salah satu faktor yang dapat menunjukkan bagaimana kegiatan UPK tersebut berjalan secara efektif adalah dengan menganalisis efektifitas program UPK. Penelitian ini menindak lanjuti penelitian yang dilakukan oleh Variyetmi Wira dan Benny Chandra (tahun 2013) pada Program Nasional Pemberdayaan Masyarakat Mandiri Pedesaan di kecamatan Koto Tengah dengan judul evaluasi kinerja pinjaman bergulir PNPM mandiri perkotaan di kecamatan Koto Tengah. Perbedaan dengan penelitian terdahulu yang akan dilakukan oleh penulis adalah terletak pada kabupaten yang akan diteliti namun sama dalam objek penelitian yang dilakukan.

\section{B. Rumusan Masalah}

Berdasarkan latar belakang masalah dan pembatasan masalah di atas, dapat dirumuskan permasalahan yang akan dipecahkan dalam penelitian ini yaitu:

Bagaimanakah efektifitas dana bergulir pada UPK PNPM Mandiri di kecamatan Mojowarno dilihat dari Cost Coverage Ratio (CCr), Return on Investment (ROI), Portofolio at Risk (PAR) dan Loan at Risk (LAR)?

\section{Metode Penelitian}

Dalam penelitian ini metode penelitian yang digunakan adalah metode penelitian deskriptif kualitatif. Pengertian metode deskriptif menurut Sugiyono $(2011: 147)$ adalah :

"Penelitian yang digunakan untuk menganalisis data dengan cara mendiskripsikan atau menggambarkan data yang telah terkumpul sebagaimana adanya tanpa bermaksud membuat kesimpulan yang berlaku untuk umum atau generalisasi"

Nana Syaodih (2008: 72) menyatakan bahwa:

"Penelitian deskriptif adalah suatu bentuk penelitian yang paling dasar. Ditujukan untuk mendiskripsikan dan menggambarkan fenomena-fenomena yang ada, baik fenomena 
yang bersifat alamiah ataupun rekayasa manusia".

Dari penjelasan kutipan diatas dapat disimpulkan bahwa penelitian deskriptif adalah mendiskripsikan atau mengambarkan data dari suatu objek, dan menggambarkan fenomena yang bersifat alamiah ataupun rekayasa.

Penelitian kualitatif adalah penelitian yang bermaksud untuk memahami fenomena tentang apa yang dialami oleh subjek penelitian misalnya perlaku, persepsi, motivasi, tindakan, dan lain-lain, secara holistic dan dngan cara deskripsi dalam bentuk kata-kata dan bahasa, pada suatu konteks khusus yang alamiah dan dengan memanfaatkan metode alamiah (Moloeng 2007:6).

Moleong (2010 : 4) mendefinisikan metodologi kualitatif sebagai prosedur penelitian yang menghasilkan data deskriptif berupa kata-kata tertulis atau lisan dari orang-orang dan perilaku yang dapat diamati.

Dari kesimpulan beberapa ahli diatas dapat dijelaskan bahwa penelitian deskriptif kualitatif adalah penelitian yang menafsirkan, mengambarkan, menyimpulkan suatu data berupa kata-kata tertulis dari orang-orang dan perilaku yang dapat diamati. Data pada penelitian ini berasal dari data Laporan Keuangan Unit Pengelola Kegiatan PNPM MPd kecamatan Mojowarno yang akan diolah atau dianalisis dalam menentukan efektifitas Unit Pengelola Kegiatan PNPM MPd.

\section{Gambaran Umum PNPM MPd Kecamatan Mojowarno}

Kecamatan Mojowarno Kabupaten Jombang Provinsi Jawa timur terdiri dari 19 desa, dengan jumlah penduduk 94.591 jiwa, 26.264 KK. Sebanyak 8.791 KK (33,4\%) dikategorikan keluarga miskin. Mata pencaharian masyarakatnya mayoritas adalah petani, pedagang, pengrajin genting, home industri (dompet, tas dari bahan kain perca, tempat alat-alat tulis dari bahan plastik) dan potensi sumber daya alam yang potensial adalah wana wisata sumberboto yang berlokasi di desa Japanan Kecamatan Mojowarno, adapum produk unggulannya adalah genting, bata merah, padi dan jagung.

Kecamatan ini terletak di arah timur $(14 \mathrm{Km})$ dari ibukota kabupaten dan barat $(80 \mathrm{Km})$ dari arah ibukota Provinsi jawa 
timur yang dapat dijangkau dengan perjalanan darat dari arah ibukota kabupaten kurang lebih selama 30 menit dan dari arah ibukota provinsi kurang lebih 2 jam.

Kecamatan ini telah berpartisipasi dalam PPK sejak tahun 2003 dan telah diganti pemerintah menjadi PNPM MPd pada tahun 2007. Kemmudian pada tahun 2008, kecamatan Mojowarno merupakan kecamatan di Kabupaten Jombang yang menjadi lokasi Program Nasional Pemberdayaan Masyarakat Mandiri Perdesaan (PNPM-MPd). PNPM bertujuan untuk percepatan penanggulangan kemiskinan yang terpadu dan berkelanjutan dengan sistem Buttom Up dan bukan Top Down, yang artinya bahwa program ini direncanakan oleh masyarakat yang paling bawah dengan melibatkan semua unsur masyarakat yang mengacu pada kebutuhan riil, bukan pada keinginan masyarakat dengan memprioritaskan maanfaatnya bagi Rumah Tangga Miskin (RTM).

1. Unit Pengelola Kegiatan (UPK) Kecamatan Mojowarno

Dalam upaya melakukan perubahan sosial, pemerintah dan masyarakat di wilayah kecamatan lokasi PNPM-MPd membentuk lembaga di tingkat Kecamatan, yaitu Unit Pengelola Kegiatan (UPK), yang bertindak sebagai pengimplementasi kegiatan-kegiatan PNPM-MPd di tingkat Kecamatan. UPK dibentuk oleh forum MAD sebagai lembaga pengelola dana PNPM baik dari dana hibah ke masyarakat maupun dana pinjaman bergulir dengan fungsi memberikan pelayanan kepada masyarakat miskin dan marginal dengan tetap melibatkan masyarakat secara umum.

Kantor UPK berada di kantor camat Mojowarno yang beralamat di Jl. Merdeka No. 88 Mojowarno. Pada awal terbentuknya UPK PNPM Kecamatan Mojowarno yakni pada tahun 2008 terdiri atas 3 (tiga) pengurus UPK yaitu Ketua, Sekretaris, dan Bendahara. Seiring berjalannya waktu dan makin besarnya aset yang dimiliki UPK PNPM Mojowarno merekrut 1 staf menjadi 4 orang staf yang terdiri dari Ketua, staf administrasi, staf Keuangan, dan kasir. UPK PNPM sendiri berada di bawah naungan lembaga yang disebut dengan Badan Kerjasama Antar Desa

(BKAD). 
2. Visi dan Misi Unit Pengelola Kegiatan (UPK) Kecamatan Mojowarno

i. Visi UPK Kecamatan Mojowarno

Visi UPK Kecamatan Mojowarno adalah mewujudkan masyarakat yang cerdas, berkarya dan mandiri

ii. Misi UPK Kecamatan Mojowarno

Dalam menjalankan kegiatannya, UPK kecamatan Mojowarno memiliki misi untuk mewujudkan visinya diantaranya:

1. memfasilitasi kepentingan masyarakat kecamatan secara keseluruhan

2. Menfasilitasi kegiatan masyarakat miskin dalam layanan permodalan usaha

3. Peningkatan produk unggulan daerah

4. Perluasan jaringan kerja

3. Struktur Organisasi dan Sumber Daya Manusia

i. Struktur Organisasi

Dalam menjalankan kegiatan serta operasionalnya, UPK menyusun staf-staf yang memiliki tugas untuk melayani masyarakat. UPK PNPM sendiri berada di bawah naungan lembaga yang disebut dengan Badan Kerjasama Antar Desa (BKAD). Berikut adalah susunan pengurus UPK PNPM Kecamatan mojowarno beserta Kelembagaan BKAD yang terbentuk sampai dengan saat ini: 
Analisis Efektifitas Program Pinjaman Dana Bergulir pada ...

Gambar 4.2 Struktur Organisasi UPK Kecamatan Mojowarno

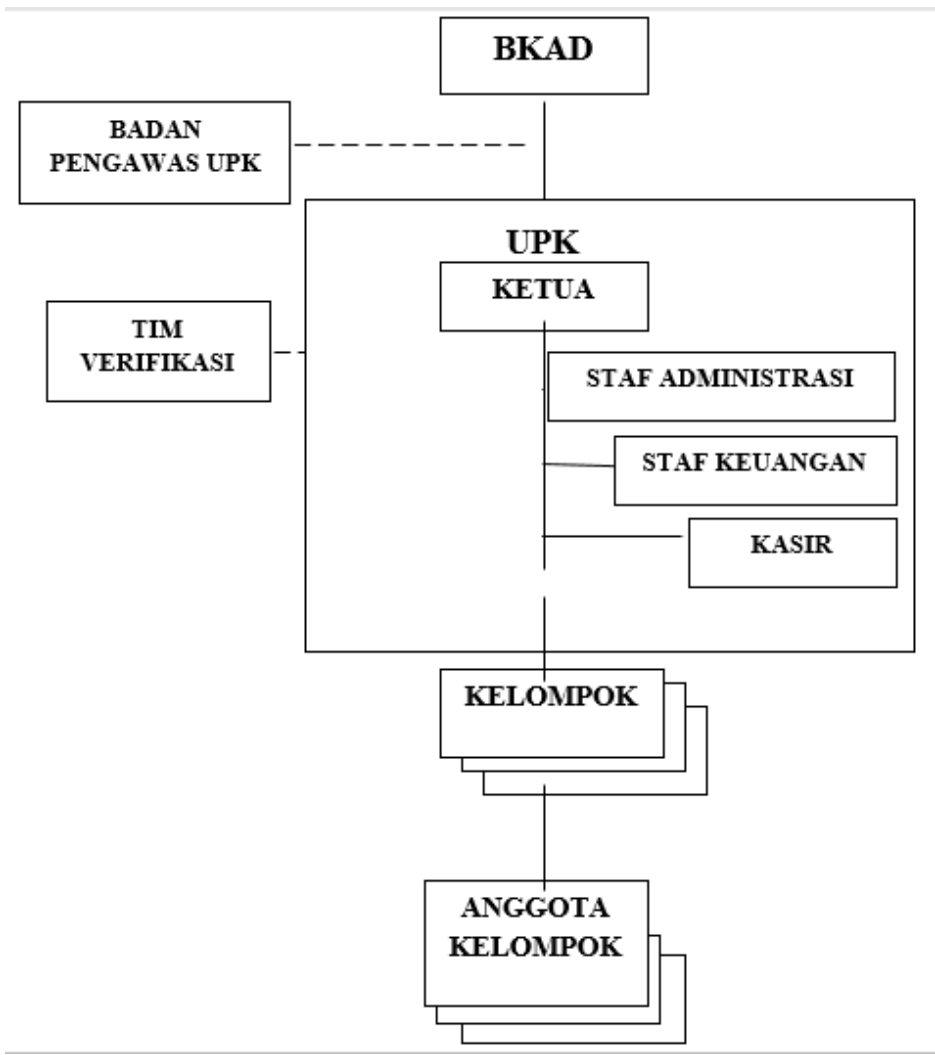

Sumber: UPK Kecamatan Mojowarno, 2014

ii. Sumber Daya Manusia

Jumlah seluruh staf UPK kecamatan Mojowarno pada tahun 2014 berjumlah 4 orang. Uraian tenaga kerja UPK Kecamatan Mojowarno sebagai berikut:

Tabel 4.1

Profil Tenaga Kerja Berdasarkan Jabatan dan Pendidikan

\begin{tabular}{|llll|}
\hline No & Nama & Jabatan & Pendidikan \\
\hline 1. & Nur Kholis & Ketua & Strata I \\
\hline 2. & Bagus Unggul P. & Staf administrasi & Strata I \\
\hline 3. & Musholliyah & Staf Keuangan & Strata I \\
\hline 4. & Anita Wahyuni & Kasir & Strata I \\
\hline
\end{tabular}

Sumber: UPK Kecamatan Mojowarno, 2014. 


\section{Pembagian tugas (Job Description) Tenaga Kerja UPK}

\section{Ketua UPK}

Ketua UPK memiliki peran sebagai penanggung jawab operasional kegiatan UPK yang memiliki tugas sebagai berikut:

a. Melakukan pengendalian terhadap semua sumber daya yang ada di UPK

b. Memfasilitasi dan mengkoordinir pertemuanpertemuan teknis pelaksanaan kegiatan

c. Mendelegasikan sebagian atau seluruh wewenangnya (dalam kondisi tertentu) sesuai kebutuhan kepada pengurus UPK yang lain

d. Bertanggung jawab atas ketersediaan dan keakurasian laporan UPK

e. Menandatangani surat perjanjian kredit (SPK) dengan kelompok yang diketahui oleh kepala desa/ kelurahan

f. Menandatangani surat-surat keluar, laporan, pencairan dana dari bank, pembukuan rekening, dana operasional UPK, Dokumen, dana pengembalian pinjaman, dan lain-lain

g. Bersama pengurus yang lain menyusun program kerja UPK dan rencana keuangan

h. Mempresentasikan program kerja dan mempertanggungjawabkan pelaksanaan dan pengelolaan UPK baik hasil-hasil kegiatan maupun keuangan UPK

i. Memimpin rapat antar pelaku UPK dalam rangka eveluasi dan pelaksanaan kegiatan

j. Menyusun dan melaporkan hasil kegiatan keuangan setiap bulan kepada pihak-pihak terkait yang memerlukan, baik ditingkat desa, kecamatanmaupun kabupaten dan jenjang yang lebih atas

k. Membuat dan mengajukan pencairan dana BLM kegiatan perguliran dan pembiayaan lain sesuai dengan rencana kerja yang disepakati

1. Menandatangani berita acara kesepakatan dan keputusan pada saat pertemuan-pertemuan yang 
Analisis Efektifitas Program Pinjaman Dana Bergulir pada ...

membahas kegiatan UPK

\section{Staf Administrasi}

Staf administrasi memiliki wewenang sebagai penanggung jawab atas segala kearsipan dokumen dan memiliki peran dalam mewakili segala urusan ketua jika ketua berhalangan.

Adapun tugas-tugas dari staf administrasi adalah sebagai berikut:

a. Bertanggung jawab atas ketersediaan data dan informasi tentang pertanggungjawaban keuangan, kegiatan kepada masyarakat melalui papan informasi atau media lainnya

b. Bertanggung jawab atas ketersediaan data dan kegiatan kelompok, meliputi jumlah anggota, pemanfaatan pinjaman serta jenis usahanya

c. Mencatat, mendokumentasikan proses dan hasil keputusan rapat

d. Mengisi dan mencatat agenda kerja di papan rencana kerja harian

e. Bertindak sebagai humas

f. Bertanggung jawab atas pengelolaan dan pemeliharaan inventaris kantor

g. Bertanggung jawab dalam pembuatan pendokumentasian surat masuk dan keluar

\section{Staf Keuangan}

Staf keuangan memiliki peran sebagai penaggung jawab dalam pengelolaan pembukuan dan laporan keuangan. Adapun tugas-tugas staf keuangan yaitu:

a. mencatat setiap transaksi keuangan secara tertib dan tepat waktu ( hard dan soft copy)

b. membuat atau menyusun laporan keuangan secara lengkap dan akuntable

c. menarik uang di bank atas ersetujuan ketua dan diketahui oleh fasilitator kecamatan dan wakil masyarakat yang sudah ditetapkan dalam MAD

d. menerima angsuran kelompok dan menyetorkan 
uang ke bank atas sepengetahuan ketua dengan didampingi oleh pengurus lain

e. menyusun daftar tagihan terhadap pinjamanpinjaman yang sudah jatuh tempo dan pinjaman yang tertunggak

\section{Kasir}

Kasir memiliki wewenang dalam memegang dan menyimpan uang kas operasional UPK atas persetujuan ketua sesuai batas maksimal sebesar $\mathrm{Rp}$ 500.000,00 setiap hari. Adapun tugas-tugas dari kasir adalah:

a. membuat perencanaan keuangan harian atas persetujuan ketua

b. menatakerjakan uang kas UPK pada awal hari kerja, saat operasi dan akhir hari

c. membayarkan pinjaman yang telah mendapatkan persetujuan atau putusan manajer

d. membayarkan penarikan tabungan tabggung renteng dan pengeluaran biaya lainnya yang telah mendapat persetujuan ketua

e. menerima angsuran atau pelunasan pinjaman dan jasa pinjaman atau setoran lainnya

f. menyimpan sisa uang kas (saldo kas) dan perincian kas

\section{E. Hasil Penelitian}

\section{Pehitungan Efektifitas UPK Kecamatan Mojowarno}

Laporan keuangan merupakan media untuk menilai prestasi serta kondisi suatu organisasi. Selain itu laporan keuangan juga dapat menjadi sebuah alat dalam mengambil suatu keputusan. Hasil yang penulis peroleh adalah berdasarkan analisa laporan keuangan UPK kecamatan mojowarno tahun 2014.

Perhitungan efektifitas UPK kecamatan Mojowarno tahun 2014 berdasarkan indikator kinerja dana bergulir yang telah diperkenalkan PNPM pada tahun 2007 yang diantaranya adalah efisiensi biaya (CCr), pencapaian laba (ROI), pinjaman yang tertunggak (PAR), 
Analisis Efektifitas Program Pinjaman Dana Bergulir pada ...

pinjaman yang menuggak (LAR). Maka perhitungannya adalah sebagai berikut:

a. Menghitung efisiensi biaya (CCr) tahun 2014

$$
=2,19 \text { atau } 219 \%
$$

Cost Coverage (CCr) digunakan untuk menilai kemampuan UPK dalam menutup biaya dari pendapatan yang diperolehnya. Angka ini di peroleh dari hasil membandingkan antara seluruh pendapatan yang diperoleh dari UPK dengan seluruh biaya yang dikeluarkan UPK.

Indikator $\mathrm{CCr}$ dapat ditunjukkan pada tabel dibawah ini:

Tabel 4.2

Indikator Pengukur Kinerja Dana Bergulir UPK (CCr)

\begin{tabular}{|lllll|}
\hline Indikator & Rumus & Memuaskan & Minimal & Ditunda \\
\hline $\mathbf{C C r}$ & Total Pendapatan & $>125 \%$ & $>100 \%$ & $\leq 100 \%$ \\
& $\begin{array}{l}\text { UPK } \\
\text { Tota Biaya UPK }\end{array}$ & & & \\
& & $219 \%$ & & \\
\hline $\begin{array}{l}\text { Hasil } \\
\text { Penelitian }\end{array}$ & & & & \\
\hline
\end{tabular}

Sumber: Data diolah (2014)

Hasil CCr dihitung dari perbandingan total pendapatan dengan biaya. CCr dinilai efektif apabila $>125 \%$, dinilai cukup efektif apabila $>100 \%$ dan dinilai tidak efektif jika $\leq 100 \%$.

Dalam menganalisa laporan keuangan UPK kecamatan Mojowarno tahun 2014 diperoleh CCr sebesar 219\% menunjukkan CCr dinilai efektif, yang artinya pendapatan UPK sudah mampu menutup semua biaya dalam menjalankan aktivitasnya.

Nilai CCr sebesar 219\% artinya setiap satu rupiah biaya yang dikeluarkan dapat menghasilkan pendapatan sebesar dua koma sembilan belas rupiah. Ini menunjukkan bahwa pendapatan yang 
diperoleh dapat menutup semua biaya-biaya yang harus dikeluarkan. Pendapatan ini sebagian besar diperoleh dari Jasa Pinjaman, pendapatan biaya administrasi serta pendapatan bunga tabungan bank. Sedangkan biaya yang timbul berasal dari biaya insentif petugas, administrasi kantor, transportasi dan komunikasi serta biaya cadangan resiko Pinjaman.

Indikator kinerja Cost Coverage ini terlihat bertolak belakang dengan indikator kinerja yang lain, yaitu LAR yang menyatakan kinerja keuangan Ditunda (tidak efektif). Hal ini menunjukan bahwa walaupun cukup banyak peminjam yang menunggak namun BKM masih tetap dapat menutup biaya yang timbul dari jumlah pendapatan.

b. Menghitung pencapaian laba (ROI) tahun 2014

$$
\begin{aligned}
\text { ROI } & =\frac{\text { Laba bersih }}{\text { Modal Investasi }} \\
& =\frac{264 \cdot 232 \cdot 150}{1.009 .117 .000} \\
& =0,26 \text { atau } 26 \%
\end{aligned}
$$

Return on Investment adalah kemampuan UPK untuk menghasilkan laba dari modal yang digunakan untuk pinjaman bergulir. Angka ini diperoleh dari hasil membandingkan antara laba yang diperoleh UPK dengan modal yang digunakan untuk pinjaman bergulir.

Indikator ROI dapat ditunjukkan pada tabel dibawah ini:

Tabel 4.3

Indikator Pengukur Kinerja Dana Bergulir UPK (ROI)

\begin{tabular}{|lllll|}
\hline Indikator & Rumus & Memuaskan & Minimal & Ditunda \\
\hline ROI & $\begin{array}{l}\text { Laba Bersih } \\
\text { Modal Investasi }\end{array}$ & $>10 \%$ & $>0 \%$ & $\leq 0 \%$ \\
\hline $\begin{array}{l}\text { Hasil } \\
\text { penelitian }\end{array}$ & $26 \%$ & & \\
\hline
\end{tabular}

Sumber: Data diolah (2014) 
Angka ini diperoleh dari hasil membandingkan antara laba yang diperoleh UPK dengan modal yang digunakan untuk pinjaman bergulir. Seperti tabel diatas dijelaskan bahwa ROI dinilai efektif apabila nilai $>10 \%$, kurang efektif apabila $>0 \%$ dan tidak efektif bila $\leq 0 \%$.

Pada perhitungan diatas yang telah membandingkan laba bersih dengan modal investasi UPK kecamatan Mojowarno diperoleh nilai 26\%, artinya UPK kecamatan Mojowarno tahun 2014 sudah efektif dalam menghasilkan laba. Karena ROI dikatakan efektif apabila nilai yang diperoleh $>10 \%$.

Nilai ROI pada tahun 2014 menunjukkan angka $26 \%$ artinya kemampuan UPK dalam mengelola dana bergulir sebesar Rp1.009.117.000 mampu menghasilkan laba sebesar $26 \%$ per tahun. Hasil ROI yang memuaskan dikarenakan jasa pinjaman yang ditetapkan sebelumnya sudah termasuk biaya operasional, biaya resiko pinjaman macet, dan keuntungan yang diharapkan dengan prosentase minimal $24 \%$ setahun atau $2 \%$ perbulan dihitung dari pinjaman awal mula-mula. Sehingga UPK mampu menghasilkan laba dari jasa pinjaman yang dibayarkan oleh KSM.

Semakin kecil tingkat jasa peinjaman dan semakin besar tunggakan, akan semakin kecil jasa riil yang diperoleh UPK. Dampaknya adalah keuntungan akan semakin kecil, dan akumulasi/ pemupukan modal semakin kecil. Apabila keuntungan yang diperoleh negatif maka terjadi pengurangan modal awal yang lama kelamaan akan habis yang artinya pelayanan UPK tidak bisa berkelanjutan. Sehingga UPK berusaha untuk meningkatkan laba per tahunnya agar pelayanan UPK kepada masyarakat dalam upaya meminjamkan modal usaha dapat berkelanjutan.

c. Menghitung pinjaman yang tertunggak (PAR) tahun 2014

Portofolio at Risk adalah indikator yang 
menunjukkan berapa \% pinjaman yang tertunggak. Angka ini diperoleh dari hasil membandingkan antara jumlah pinjaman yang tertunggak $>3$ bulan dengan total realisasi saldo pinjaman di UPKHasil Perhitungan PAR (Portofolio at Risk) adalah:

$$
\begin{aligned}
\text { PAR } & =\frac{\text { Pinjaman tertunggak } \geq 3 \mathrm{bln}}{\text { Realisasi saldo pinjaman }} \\
& =\frac{259.018 .650}{4.461 .650 .000} \\
& =0,06 \text { atau } 6 \% .
\end{aligned}
$$

Indikator PAR beserta hasil perhitungannya dapat ditunjukkan pada tabel dibawah ini:

\section{Tabel 4.4}

\section{Indikator Pengukur Kinerja Dana Bergulir UPK (PAR)}

\begin{tabular}{|lllll|}
\hline Indikator & Rumus & Memuaskan & Minimal & Ditunda \\
\hline & $\begin{array}{l}\text { Pinj. tertunggak } \geq 3 \\
\text { bulan }\end{array}$ & & & \\
PAR & $\begin{array}{l}\text { Realisasi Saldo } \\
\text { Pinjaman }\end{array}$ & $<10 \%$ & $<20 \%$ & $\geq 20 \%$ \\
\hline $\begin{array}{l}\text { Hasil } \\
\text { penelitian }\end{array}$ & $6 \%$ & & \\
\hline
\end{tabular}

Sumber: Data diolah (2014)

Hasil perhitungan PAR diperoleh dengan membandingkan jumlah pinjaman yang menunggak lebih dari 3 bulan dengan realisasi saldo pinjaman, PAR dinilai efektif apabila prosentasenya $<10 \%$, dinilai kurang efektif bila hasil prosentase $<20 \%$ dan tidak efektif apabila $\geq 20 \%$.

Dari perhitungan diatas dengan data yang diambil dari laporan keuangan UPK kecamatan Mojowarno tahun 2014 dapat diperoleh hasil PAR sebesar $6 \%$. Angka ini $<10 \%$ yang menunjukkan bahwa jumlah pinjaman yang tertunggak adalah masih dinilai efektif.

Hal ini dikarenakan jasa yang yang harus dibayarkan kepada UPK adalah 24\% setahun atau $2 \%$ per bulan yang artinya sudah mampu 
Analisis Efektifitas Program Pinjaman Dana Bergulir pada ...

menutupi cadangan resiko apabila ada KSM yang menunggak. Namun jika tidak ditangani dengan serius dikhawatirkan modal yang telah dipinjamkan kepada masyarakat tidak akan dapat dikembalikan akibatnya dana UPK akan habis serta anggota masyarakat yang ingin meminjam harus menunggu adanya pembayaran dari anggota yang telah meminjam sebelumnya. Prinsip dari dana bergulir adalah modal yang diberikan pada BKM yang merupakan modal permanen harus dapat dikembalikan dan digulirkan kembali ke masyarakat. Kemacetan yang cukup tinggi tentunya akan menghambat perguliran dana ke masyarakat.

d. Menghitung pinjaman yang menunggak (LAR) tahun 2014

$$
\begin{aligned}
\text { LAR } & =\frac{\text { Jumlah KSM menunggak } 3 \text { bln }}{\text { Jumlah KSM Peminjam }} \\
& =\frac{45}{212} \\
& =0,21 \text { atau } 21 \%
\end{aligned}
$$

Loan at Risk adalah indikator yang menunjukkan berapa \% KSM yang menunggak. Angka ini diperoleh dari hasil membandingkan antara jumlah KSM yang menunggak $<3$ dengan total KSM yang aktif.

Indikator LAR beserta hasil perhitungannya dapat ditunjukkan pada tabel dibawah ini:

\section{Tabel 4.5}

\section{Indikator Pengukur Kinerja Dana Bergulir UPK (LAR)}

\begin{tabular}{|lllll|}
\hline Indikator & Rumus & Memuaskan & Minimal & Ditunda \\
\hline LAR & $\begin{array}{l}\text { Jumlah KSM } \\
\text { menunggak } \geq 3 \mathrm{bl}\end{array}$ & $<10 \%$ & $<20 \%$ & $\geq 20 \%$ \\
& $\begin{array}{l}\text { Jumlah KSM } \\
\text { Peminjam }\end{array}$ & & & \\
\hline $\begin{array}{l}\text { Hasil } \\
\text { penelitian }\end{array}$ & & & $\mathbf{2 1 \%}$ \\
\hline
\end{tabular}

Sumber: Data diolah (2014)

BISNIS, Vol. 3, No. 1, Juni 2015 
Hasil perhitungan LAR diperoleh dengan membandingkan jumlah KSM yang menunggak lebih dari 3 bulan dengan jumlah KSM peminjam, LAR dinilai efektif apabila prosentasenya $<10 \%$, dinilai kurang efektif bila hasil prosentase $<20 \%$ dan tidak efektif apabila $\geq 20 \%$.

Dari data-data laporan keuangan UPK kecamatan Mojowarno tahun 2014 dapat diperoleh hasil LAR sebesar $21 \%$ yang berarti angka tersebut $\geq 20 \%$. Apabila LAR $21 \%$ dikatakan bahwa ada dari $21 \%$ KSM yang aktif mengalami kesulitan dalam membayar angsuran pinjaman sehingga LAR dinilai tidak efektif.

Pemberian kredit oleh suatu lembaga tidak terlepas dari resiko kredit macet atau pengembalian yang kurang lancar dari KSM. Masalah yang umum terjadi yaitu penagihan angsuran yang telah jatuh tempo tidak seluruhnya dapat diselesaikan. Hal ini disebabkan ketua KSM kurang bisa mengelola kelompok dengan baik sehingga anggota kelompok tidak mampu untuk melunasi kewajibannya.

Banyaknya KSM yang menunggak menyebabkan cadangan resiko juga akan meningkat sehinga apabila dibiarkan dikhawatirkan dapat mempengaruhi laba yang di hasilkan UPK

\subsection{Hasil Analisis Efektifitas UPK dan Pembahasan}

Berdasarkan hasil penilaian kinerja dana bergulir UPK pada kecamatan Mojowarno tahun 2014 dapat dibuat tabel sebagai berikut:

Tabel 4.6, Penilaian efektifitas UPK kecamatan Mojowarno

\begin{tabular}{|lll|}
\hline Indikator & Hasil Penelitan & Pencapaian \\
\hline CCr & $219 \%$ & Memuaskan (Efektif) \\
\hline ROI & $26 \%$ & Memuaskan (Efektif) \\
\hline PAR & $6 \%$ & Memuaskan (Eektif) \\
\hline LAR & $21 \%$ & Ditunda (tidak efektif) \\
\hline
\end{tabular}

Sumber: Data diolah (2014) 
Analisis Efektifitas Program Pinjaman Dana Bergulir pada ...

1. CCr (Cost Coverage)

Pada hasil perhitungan $\mathrm{CCr}$ memperlihatkan pendapatan UPK cukup besar sehingga cukup untuk membiayai aktivitas operasional UPK, setelah dianalisa dengan membandingkan pendapatan dengan biaya diperoleh hasil CCr sebesar 219\% sehingga masuk dalam kategori memuaskan atau efektif karena $>125 \%$. Hasil ini mendukung hasil penelitian yang dilakukan oleh Variyetmi Wira dan Benny Chandra (2013) yang memperoleh hasil CCr dalam kategori memuaskan.

2. ROI (Return on Investment)

Diperoleh hasil ROI sebesar 26\% menunjukkan bahwa UPK sudah efektif dalam menghasilkan laba dari modal yang digunakan karena batas nilai efektif adalah $>10 \%$. Penelitian ini menolak penelitian yang dilakukan oleh Variyetmi Wira dan Benny Chandra (2013) dengan memperoleh hasil ROI $0 \%$ yang artinya masuk dalam kategori ditunda atau tidak efektif.

3. PAR ( Portovolio at Risk)

Hasil perhitungan PAR yaitu sebesar 6\%, angka ini dinilai efektif karena $<10 \%$. Secara umum saldo tunggakan yang tidak terbayar masih dinilai efektif karena nominalnya yang tidak terlalu besar. Penelitian ini menolak penelitian yang dilakukan oleh Variyetmi Wira dan Benny Chandra (2013) yang memperoleh hasil PAR dalam kategori ditunda atau tidak efektif.

4. LAR (Loan at Risk)

Nilai LAR tinggi menunjukkan bahwa banyak KSM yang tidak membayar angsuran pinjaman, penyebab tidak dibayarkannya angsuran adalah kurangnya kesadaran masyarakat akan pentingnya dana bergulir bagi masyarakat. Hasil LAR diperoleh sebesar $21 \%$ yang masuk dalam kategori ditunda atau tidak aefektif karena $\geq 20 \%$. Hasil ini mendukung penelitian yang dilakukan oleh Variyetmi Wira dan Benny Chandra (2013) yang memperoleh hasil LAR yang masuk dalam kategori ditunda.

\section{F. Simpulan}

Dari hasil analisis laporan keuangan yang penulis lakukan terhadap efektifitas dana bergulir UPK PNPM MPd pada UPK 
kecamatan Mojowarno tahun 2014 dengan menggunakan indikator kinerja PNPM berupa CCr, ROI, PAR, dan LAR, secara umum terlihat bahwa kinerja UPK menghasilkan nilai yang baik atau efektif.

Terlihat nilai CCr (Cost Coverage) sebesar 219\% dengan batas nilai efektif sebesar $>125 \%$ yang menunjukkan pendapatan UPK cukup besar untuk membiayai semua operasional UPK. Kondisi ini mengindikasikan UPK telah mampu mandiri dari segi pendapatan yang dihasilkan sehingga UPK mampu menutup semua kegiatan operasionalnya. Serta nilai ROI (Return on Investment) yang menunjukkan angka $26 \%$ dengan batas nilai $>10 \%$ yang artinya UPK dinilai sudah efektif dalam menghasilkan laba sebesar $26 \%$ per tahun darimodal awal.

Namun pada hasil perhitungan LAR (Loan at Risk) terlihat bahwa diperoleh hasil 21\% yang berarti masuk dalam kategori tidak efektif dengan batas nilai $\geq 20 \%$ yang memperlihatkan bahwa ada 21\% KSM yang menunggak pinjaman lebih dari 3 bulan, namun hal ini hanya sedikit mempengaruhi hasil dari PAR, karena jika dibandingkan jumlah tunggakan dengan realisasi pinjaman, diperoleh hasil PAR (Portofolio at Risk) yaitu sebesar $6 \%$ yang artinya efektif dengan batas nilai $<10 \%$ dengan kategori memuaskan atau efektif. Hal ini disebabkan karena penetapan jasa pinjaman sudah termasuk cadangan resiko pinjaman. 
Analisis Efektifitas Program Pinjaman Dana Bergulir pada ...

\section{DAFTAR PUSTAKA}

Baroroh, Ali. 2013. Analisis Multivariate dan Time Series dengan SPSS 21. Jakarta: Kompas Gramedia.

Husein,U. 2005. Riset Sumber Daya Manusia Dalam Organisasi. PT. Gramedia Bumi Pustaka Utama. Jakarta.

Kamus Besar Bahasa Indonesia, 2003. Pengertian Analisis. Jakarta : Salemba Empat.

Krisnawati, Yohana Andreas.2013. Dampak Program Nasional Pemberdayaan Masyarakat Mandiri Perdesaan (Pnpm-Mp) Terhadap Peningkatan Perekonomian Masyarakat Di Desa Tlanak Kecamatan Kedungpring Kabupaten Lamongan. Universitas Negeri Malang: Malang.

Masruri. 2010. Analisis Efektifitas Program Nasional Pemberdayaan Masyarakat Mandiri Perkotaan (PNPM-MP). Journal Of Convernance And Public Policy.

Pengesti, Iin Nimang. 2012. Implementasi Program Nasional Pemberdayaan Masyarakat Mandiri Perdesaan (PNPM-MP) di Desa Sonowangi Kecamatan Ampelgading Kabupaten Malang. Universitas Negeri Malang: Malang.

Prastowo, Dwi dan Julianty, Rifka. 2008. ANALISIS LAPORAN KEUANGAN Konsep dan Aplikasi. Edisi ke Dua. UPP STIM YKPN: Yogyakarta.

Rahmatika. 2011. Analisis Efektifitas Program injaman Dana Bergulir Pada Unit Pengelola Kegiatan (UPK) di Kecamatan Situjuh Limo Magari Kabupaten Lima Puluh Kota Tahun 2008-2011. Universitas Andalas: Padang.

Sugiyono. 2010. Metode Penelitian Bisnis (Pendekatan Kuantitatif, Kualitatif, dan RED). Alfabeta: Bandung. 
Agus Taufik H. SE, MM.

Sugiyono. 2011. Metode Penelitian Kuantitatif Kualitatif dan R \& D, Alfabeta: Bandung

Wira, Variyetmi dan Benny Chandra. 2013. Evaluasi Kinerja Pinjaman Bergulir PNPM Mandiri Perkotaan di Kecamatan Koto Tengah. Politeknik Negeri Padang : Padang

2014. Petunjuk Teknis Operasional Program Nasional Pemberdayaan Masyarakat (PNPM) Mandiri Pedesaan. Dirjen Pemberdayaan Masyarakat dan Desa. 